\title{
The Smartphone as a Pedagogic Tool. Student Profiles as related to its Use and Knowledge
}

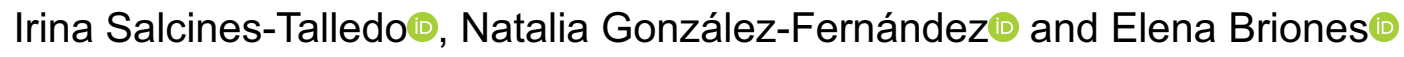 \\ Department of Education, University of Cantabria, Spain
}

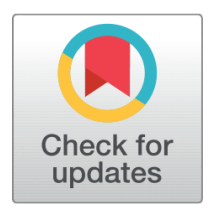

Received 2019-07-09

Revised 2019-09-16

Accepted 2019-11-07

Published 2020-01-15

Corresponding Author

Irina Salcines-Talledo,

salcinesi@unican.es

Universidad de Cantandria, Departamento de Educación, Avda de Los Castros, s/n. 39005 Santander

DOI https://doi.org/10.7821/ naer.2020.1.454

Pages: 91-109

Distributed under

Creative Commons CC BY 4.0

Copyright: (C) The Author(s)

\section{OPEN ACCESS}

\section{ABSTRACT}

The Smartphone has become the device that offers the greatest number of possibilities to Mobile Learning dynamics, and university students are increasingly optimizing its potential. This research offers a classification of student profiles according to their knowledge and use of Smartphones, and analyzes their relationship between their interest towards training, the perceived academic benefits and the time spent using the device as a pedagogic resource. For this, through a quantitative methodology, a cluster analysis was conducted, which allowed for the defining of student profiles, and through non-parametric tests, the significance was analyzed with respect to their interest in training, the academic benefits perceived, and the time spent using the Smartphone. The results showed the existence of three profiles, namely: High degree of knowledge and academic use of the Smartphone; Average degree of knowledge and use of the Smartphone; and Low degree of knowledge and use of the Smartphone. Also, differences between the profiles were found in the time spent using it, the benefits perceived and the interest for being trained on the academic use of the Smartphone. The students with the Low profile were the ones that detected the least number of positive aspects and had the least interest in training towards this aim.

Keywords SMARTPHONE, UNIVERSITY STUDENTS, MOBILE LEARNING, MEDIA IN EDUCATION, TEACHING/LEARNING STRATEGIES

\section{INTRODUCTION}

Information and Communication Technologies (ICT) have substantially changed social and educational dynamics. In this sense, the use of the Internet and social networks have had great repercussions in formal as well as informal learning, therefore, regulating their use through mental and behavioral strategies is essential (Wu, 2015).

It is important to delve into the knowledge possessed by the students on the new technological tools. Despite dealing with a generation that (Prensky, 2001, 2011) labeled "Digital Natives", these individuals do not always possess all the skills and competencies necessary to allow them to make use of these technologies in a safe and adequate manner, just as shown in various research studies. Some of these studies have even pointed to the inadequacy of 
using age as the differentiating criteria between digital "Natives" and "Immigrants" (Lluna \& Pedreira, 2017; Yang, Huang, \& null Kinshuk, 2016). Therefore, it is important to delve into the type of knowledge the students possess as related to the ICT, so that we do not assume that this knowledge is always found in all of them by default.

University students are immersed in the so-called "Society of Learning", which emphasizes that at present, everyone can independently access knowledge and learn, regardless of their situation and context Cisco (2010). The multiple benefits of this type of society are undeniable. For example, the free access to information, the establishment of new pedagogic practices with technological tools, the generalized dissemination of constant learning and life-long learning, among others, is now possible. However, possible limitations and dangers such as infoxication (Aguaded, 2014), the development of a pre-fabricated e-identity (Gardner \& Davis, 2014), social exclusion through the digital divide or dependency (Sevillano, 2013), should also be reflected upon. Thus, we find ourselves with Higher Education students who are highly familiar with technology and an almost unlimited access to information, but in many cases they do not have the necessary information for selecting, analyzing or integrating this information, as well as little knowledge on how to use these technological tools for educational goals.

These changes have been accompanied by the use of new technological devices (Chen, Woolcott, \& Swellert, 2017), with the Smartphone being the one that offers the greatest number of options for learning thanks to the development of mobile applications and the promoting of "Ubiquitous learning".

Likewise, the Smartphone is the device with the greatest global omnipresence. A recent report indicates that $82.3 \%$ of internet users used the Smartphone as the device of choice for their connections, followed by the computer (81.2\% and the Tablet (34.4\%) (Fundación Telefónica, 2016). Along the same lines, (Ericsson, 2016) foresees that in the year 2021, there will be 9 billion mobile subscriptions, 7.7 billion mobile broadband subscriptions and 6.3 billion Smartphone subscriptions.

Faced with this reality, recent research studies have begun to analyze the influence of Smartphones on Higher Education students, with many of these research studies focused on the negative aspects of its use. Kibona and Mgaya (2015), additionally Carbonell, Chamarro, Oberst, Rodrigo, and Padres (2018), point to the use of social networks as a problem for the student's learning. Along the same lines, Rozgonjuk, Saal, and Täht (2018), highlight how the use of social networks favors a superficial focus on learning, which has negative repercussions for academic results. However, Razzaq, Samiha, and Anshari (2018), offer a more optimistic view, pointing to the multiple possibilities offered by smartphones for students for conducting their academic activities, pointing to the importance of the selfefficiency perceived by the students, the use they give to the tool and their knowledge about it, as a few of the key concepts that determine the greater or lesser success of its pedagogic use.

Thus, this study delves into the knowledge about the pedagogic possibilities of the Smartphone as a technological tool at the service of a teaching-learning-evaluation processes in the sphere of Higher Education, addressing the repercussions from the knowledge and use 
of the Smartphone by students in the academic context. More specifically, the objective of this research is focused on establishing a classification of university student's profiles related to their knowledge of the Smartphone, while at the same time, their relationship with the time spent with the device, their interest towards training and the pedagogic benefits perceived will be analyzed. In this way, the results will hopefully lead to a re-thinking of the current methodological and training proposals by providing options for each profile obtained.

\section{THEORETICAL FRAMEWORK}

One of the first authors to define the concept of Mobile Learning was Quinn (2000), who explained that it was an evolution of eLearning with mobile devices that allowed for ubiquitous learning, anytime and anywhere. Likewise, Traxler (2005) and Keegan (2005) emphasized the role of mobile technologies as mediators of learning, and malley, Vavoula, Glew, Taylor, and Sharples (2005) reflected on the importance of mobility, meaning, learning that takes place when the student is not in a fixed place.

Different authors have investigated the multiple advantages of this type of learning, such as the possibility of mobility, accessibility, collaboration or interaction, among others Camacho (2011). Mojarro, Duarte, Guzman, and Aguaded (2019), indicated that the university students had a high pre-disposition towards the use of mobile devices for learning. However, recent studies place stress on the importance of educators using mobile technologies to develop significant learning experiences for the students (Heflin, Shewmaker, \& Nguyen, 2017), that are efficient and adapted to educational objectives (Sung, Change, \& Liu, 2016), without focusing their attention on the use of technology over the pedagogical goals (Marcelo, Yot, \& Mayor, 2015). Likewise, authors such as (Tabuenca, Verpoorten, Ternier, Westera, \& Specht, 2013) place stress on the independence of the training model (analog or digital) in the development of competencies and skills, specifying that what is truly important is that the students autonomously, consciously and freely choose when and where to use the technology for their educational benefit.

Of all the devices that can be used for Mobile Learning, the Smartphone, even when taking into account its limitations, is the best (Brazuelo \& Cacheiro, 2010; Brazuelo \& Gallego, 2011; Cerezo, 2010; Cochrane \& Bateman, 2010; Contreras, Herrera, \& Ramírez, 2009; Ramos, Herrera, \& Ramírez, 2010; Sevillano, 2013).

The potential of these devices should be taken advantage of in order to create wellfounded educational experiences that are enriched by the device's potential. In this sense, some authors have pointed to the importance of working in the creation of educational programs that result, among the educators and student collectives, in an attitudinal change in their pre-disposition towards the development of high-quality teaching-learning activities (Batanero \& González, 2015; Tejedor, García-Valcárcel, \& Prada, 2009) that fusion cooperation, creativity and the critical construction of knowledge meditated by technology.

In this context, the student is the main protagonist in his or her learning process, in which he or she must play a leading, participative and active role within his or her educa- 
tional itinerary (Espinosa, Jiménez, Olabe, \& Basogain, 2006) (Espinosa, Jiménez, Olabe \& Basogain, 2006). For this, it is important to diversify and hybridize the time and space for instruction, developing educational itineraries that are stimulating, critical and constructive, diversifying the teaching and learning methodologies (Lleixà, Gros, Mauri, \& Medina, 2018) and, as highlighted by Tiana (2013), precisely applying technology in the educational sphere.

In this scenario, the profiles of knowledge and pedagogic use of the university students in relation to technology have started to be analyzed. In previous research, authors such as Kennedy, Judd, Dalgarno, and Waycott (2010) have pointed to the heterogeneity of the students as related to the use of technology. In their research, they identified four student profiles that confirmed the diversity of the student body as related to their experience with technology. The first profile was named "Power users", the second "Ordinary users", the third "Irregular users" and the fourth "Basic users". The students placed in the first profile, who showed a high degree of technological mastery, comprised less than $15 \%$ of the students polled, pointing to the error of defining the new generations as "Digital Natives". It should be noted, however, that the "Ordinary users" had a slightly higher use of the Smartphone as compared to the "Power users".

For their part, (Henríquez, González, \& Organista, 2014) proposed a classification of Smartphone user profiles starting with a representative sample of university students and professors. In this case, the authors established two student profiles, one of low use, referring to the low frequency of use and skill, and another of advanced use, represented by students that had a high skill and frequency of use of the Smartphone for educational aims, as well as a good mastery of the English language.

Likewise, a study conducted by García, Ortí, Rodríguez, and Abad (2015), established three profiles of technological competencies and three profiles of pedagogic competencies of university students, tending to the variables: accessibility to computer equipment, knowledge of ICT, use of ICT and attitudes towards the ICT. In the profiles related to technological competencies, as well as those related with the pedagogic competency, three groups were established, named "High level", "Medium level" and "Low level". Both "High level" groups, meaning the group of those who possessed a greater knowledge about the use of technology, and those who used the ICT with educational goals, were comprised by a lesser number of students.

This study will explore and move deeper into the relationship of the university students with technology, more specifically, the Smartphone. This technology is, as justified, one of the tools that offers the greatest pedagogic possibilities; pedagogy, as understood by the term promoted by the UNESCO (1999), which transcends the traditional didactic conceptions, and involves the educator and the student as the protagonists of the learning actions. With this in mind this research will delve into the relationship of the variables that have already been independently addressed in previous research studies, such as knowledge (Razzaq et al., 2018), use (Kibona \& Mgaya, 2015), or training (Razzaq et al., 2018). However, in this case, the research will delve into the relationships between knowledge and use of the smartphone with the time spent with the device, the benefits perceived from its 
use and the interest of being trained on the academic use of the Smartphone. The information obtained will be used to offer guidelines to foment the pedagogic use of this technology.

\section{METHODS}

\subsection{Sample}

The sample was comprised of 483 students from the University of Cantabria enrolled in different areas of knowledge representing the entire set of degrees in that university $(\mathrm{N}=11658)$, with a margin of error of $5 \%$ and a degree of confidence above $97 \%$.

The sample had a differential distribution according to gender, with a predominance of women (30.2\% men and $69.8 \%$ women), with $18 \%$ of those polled aged less than 20 years old, $61.1 \%$ aged between 20 and 25 years old, and $20.9 \%$ older than 25 years old.

As for their academic year, $22.1 \%$ were 1 st year students, $14.4 \%$ were 2 nd year, $20.0 \%$ were 3 rd year, $31.2 \%$ were 4 th year, and $12.3 \%$ were Masters students.

As for their areas of knowledge, most of them (68.8\%) belonged to the Social and Judicial Sciences (see Figure 1).

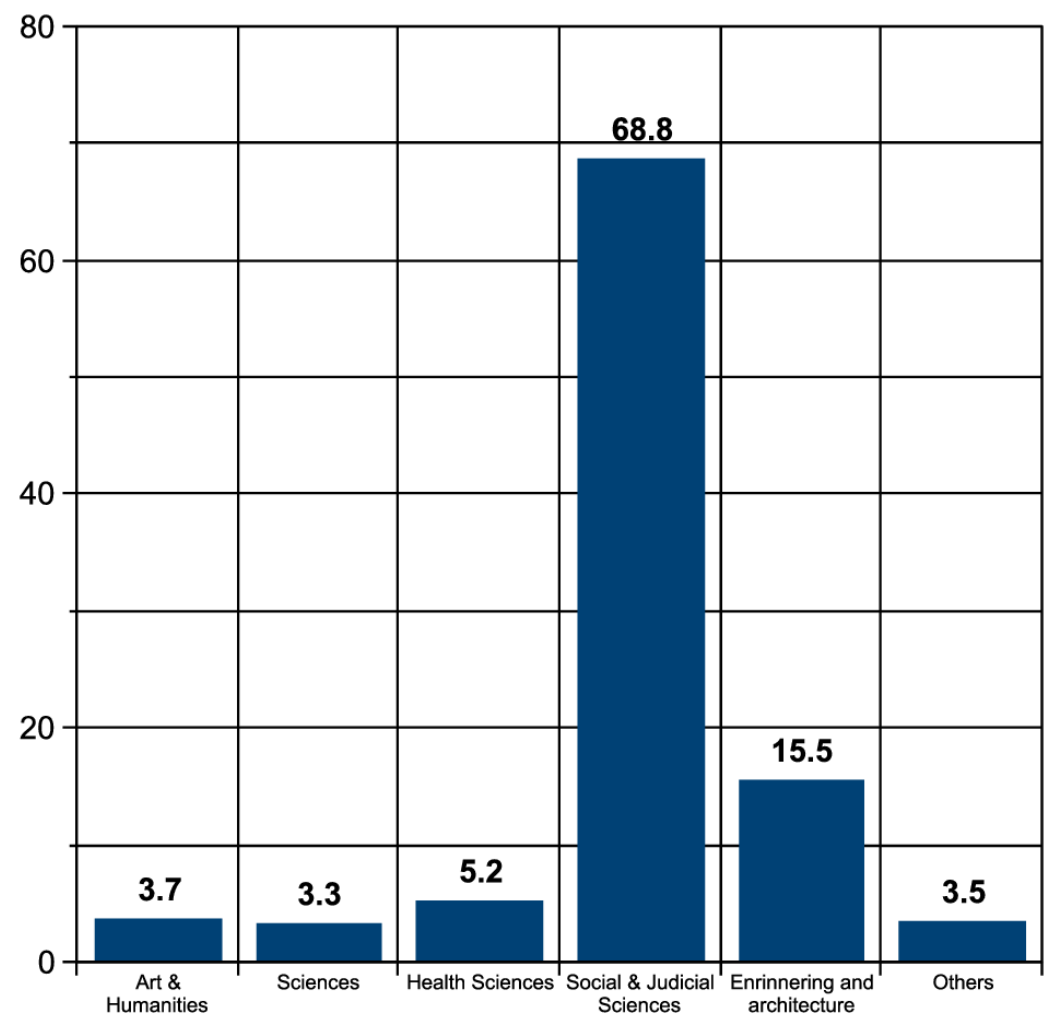

Figure 1 Sample distribution according to Area of knowledge 


\subsection{Instruments}

In this study, the instrument "Smartphone and University Questionnaire. Student Perspective. SUQS"1 (Salcines-Talledo \& González-Fernández, 2015), was used. The instrument's internal consistency, calculated with Cronbach's Alpha, was .97, thereby showing the high reliability of the tool (Mcmillan \& Schumacher, 2005). Likewise, the KMO test provided a value of .835 , indicating a high relationship between the variables as it is close to 1 , and Bartlett sphericity test $(\chi 2=3704.693 ; \mathrm{gl}=300 ; p<.000)$ also indicated the adequacy of the factorial analysis carried out (Hair, Black, Babin, \& Anderson, 2009). In order to obtain information on the relationship between Smartphones and university students, the variables that provided answers to the objectives set in this article were analyzed. For all of them, Cronbach's Alpha was used to ensure their suitability, except for the variables that were comprised by two items. For these, the Spearman-Brown reliability estimate was more appropriate, as underlined by Eisinga, Grotenhuis, and Pelzer (2013).

- The socio-demographic and academic variables were; gender, age, academic year and area of knowledge.

- The cluster analysis variables were related to the knowledge and use of the Smartphone:

- "Knowledge of the Smartphone", this variable refers to the knowledge possessed by the students about this technological tool and its applications at the personal and academic level. It is composed of four items "I know what a Smartphone is", "I know what Smartphone applications are", "I know how to download Smartphone applications" and "I am aware of Smartphone applications that are useful for my academic activity". The variable had an appropriate reliability $(\alpha=.76)$.

- The variable "Use for Communication and Management" alludes to the academic use given to the tool by the students, for communication, organization and management tasks. It was composed of items "I use the Smartphone to communicate with my classmates about academic aspects" and "I use the Smartphone as a tool for academic management and organization". Its reliability was moderate $(\mathrm{p}=.51)$.

- "Pedagogic use", lastly, this variable refers to the frequency of use of the Smartphone by the students, in the different teaching methods promoted by the professors, according to De Miguel's classification (2006), adapted to the context of the University of Cantabria. It was composed of items: "Master Class", "Participative Master Class", "Cooperative Learning”, "Problem-based Learning", "Project Design", "Laboratory Practices", "Portfolio Development", "Other Methodologies" and for the item "Use of the Smartphone in the process of teaching-learning-evaluation". This variable had a very high reliability $(\alpha=.93)$.

- The dependent variables that were used were the following three:

\footnotetext{
${ }^{1}$ https://encuestas.unican.es/encuestas/index.php/779387?lang=es
} 
- "Training interest", relative to the student's interests for receiving and attending specific training sessions on how to take advantage of the pedagogic possibilities of the Smartphone. It was composed of two items: "I would like to receive more specific training on how to take advantage of the Smartphone in learning tasks" and "If more training courses were conducted for understanding the possibilities that Smartphones offer in the process of teaching-learning, I would attend". The reliability was adequate $(\alpha=.85)$.

- "Time spent" addresses the daily amount of time spent by the students with their Smartphone for academic tasks. It was composed of the item "Indicate the daily amount of use of the Smartphone for academic aims".

- "Perceived academic benefits" collects the student's perceptions on the benefits of the pedagogic use of the Smartphone. It was comprised of eight items related to the benefits given to the students through the use of a Smartphone: "It allows me to quickly search for information", "It allows me to access content anytime and anywhere", "It improves my access to documents for reading", "It improves my ability with languages thanks to applications such as translators", "Grants me more assurance when doing homework as it allows me to contact my classmates at any time", "It is convenient as the device can be taken anywhere", "It allows me to access content in different languages" and "It allows for learning through the mechanics and techniques of educational games". This variable showed an acceptable reliability $(\alpha=.86)$.

The answer scale of the cluster analysis variables and the study's dependent variables were Likert-type, with four answer options (1: completely disagree; 2 : disagree; 3: agree, 4: completely agree), except for the variable "Time spent" (1: less than an hour per day; 2 : around an hour per day; 3 : around 2 hours per day; 4 : around 3 or more hours per day).

\subsection{Data gathering procedure}

The questionnaire was provided online to the students during the 2014-2015 academic year through the LimeSurvey platform. This platform facilitates the sending of the questionnaire's online link via email to the entire student body and the posterior storing of the answers in a database that can be easily exported for later analysis.

\subsection{DATA ANALYSIS}

In first place, the normality of the sample was analyzed in each of the variables studied with the Kolmogorov-Smirnov (K-S) test. As the results showed a lack of normality (see Table 3), non-parametric tests were conducted on the analysis conducted with the cluster analysis (independent variable) and the rest of the variables studied (socio-demographic, professional and dependent). More specifically, the Kruskal-Wallis test (for variables with three or more categories), the Mann-Whitney test, applied to two independent variables; Wilcoxon signed rank-test for related samples; the binomial test and the Chi-square test for a single sample. 
In second place, possible multivariate outliers were identified in the cluster variables, leading to a lineal regression analysis of the cluster analysis variables on the ID (Variable of Identification) in order to obtain the Mahalanobis distance. The analysis identified four atypical values. Afterwards, by following the indications by Picón, Varela, and Real (2003), hierarchical cluster analyses were combined in order to de-confirm the presence of these atypical values and to determine the number of clusters and their initial centers, with $\mathrm{K}$ means cluster analysis in order to obtain a final cluster solution.

In the first phase of hierarchical cluster analysis, a nearest-neighbor method was used for the detection, observation and elimination of outliers. As the previously noted values were once again detected, the next analysis was used to eliminate them. The Ward's grouping method was used to obtain the number of clusters.

The solutions of three, four and five clusters were compared to find the best solution (Hartigan \& Wong, 1979). Both the efficiency rule (i.e. smallest but sufficient number of clusters) and the effectiveness rule (i.e., theoretically and empirically meaningful groups) were used (Johnson, 1998; taken from $\mathrm{Wu}, 2015$ ) to decide the optimal number of clusters. Also, a hierarchical cluster analysis was conducted with the average linkage distance within groups in order to study the stability of the cluster solutions resulting from the Ward method.

In a second phase of cluster analysis, the K-means method was used with the files containing the means that were obtained via the hierarchal method and the Ward's distance as the initial centers in order to offer a final cluster solution. All of these analyses were conducted with the SPSS v.22 program.

\section{RESULTS}

\subsection{Descriptive analysis and cluster analysis}

Table 1 shows the main statistical results from the variables and values from the Kolmogorov-Smirnov test, showing the lack of normality of the data distribution in all the study variables.

The hierarchal cluster analysis with Ward's distance offered a solution of three clusters, which was considered as the most adequate as it obtained clusters of a similar size and similar dispersion of their elements. Its stability was posteriorly confirmed through a hierarchal cluster analysis, using as the distance the linkage within groups. Also, the correlation of this solution, along with that offered by the K-means cluster analysis was .812 $(p<.01)$. In total, 77 cases out of 439 were re-assigned when the K-means method was used (17.5\%). This was the final cluster solution taken into account, and later analyses conducted with the cluster variable and the study variables were performed with 439 data points, not taking into account the 40 that had failed to classify due to the loss of data in the cluster variables.

\subsection{Analysis and description of the profiles}

The results of the posterior non-parametric analysis with the final cluster variable and the variables from the cluster analysis related to the knowledge and use of the Smartphone were 
Table 1 Statistical results of the study variables

\begin{tabular}{|c|c|c|c|}
\hline Socio-demographic and academic variables & & Percentages & $\mathbf{K}-\mathbf{S}^{*}$ \\
\hline \multicolumn{4}{|l|}{ Gender } \\
\hline Male & & 30.3 & \\
\hline Female & & 69.7 & .442 \\
\hline Age & & 19.4 & .309 \\
\hline Younger than 20 years old & & 61.7 & \\
\hline From 20 to 25 years old & & 18.9 & \\
\hline \multicolumn{4}{|l|}{ Older than 25} \\
\hline Academic year & & & .211 \\
\hline 1st Year & & 22.1 & \\
\hline 2nd Year & & 14.4 & \\
\hline 3rd Year & & 20.0 & \\
\hline 4th Year & & 31.2 & \\
\hline Masters student & & 12.3 & \\
\hline Area of knowledge & & & .367 \\
\hline Arts and Humanities & & 6.0 & \\
\hline Sciences & & 3.6 & \\
\hline Health Sciences & & 6.7 & \\
\hline Social and Judicial Sciences & & 62.9 & \\
\hline Engineering and Architecture & & 17.6 & \\
\hline Others & & 3.3 & \\
\hline Cluster analysis variables & Mean & Standard Deviation & $\mathbf{K}-\mathbf{S}^{*}$ \\
\hline Knowledge about Smartphones & 3.54 & 0.41 & .190 \\
\hline Use in Communication-Management & 3.48 & 0.64 & .272 \\
\hline Pedagogic Use & 1.45 & 0.59 & .220 \\
\hline Dependent variables & Mean & Standard Deviation & $\mathbf{K}-\mathbf{S}^{*}$ \\
\hline Time spent & 1.67 & 0.89 & .330 \\
\hline Academic Benefits Perceived & 3.32 & 0.58 & .118 \\
\hline Training Interest & 2.67 & 0.95 & .168 \\
\hline
\end{tabular}

Note: Source: author created. ${ }^{\star}$ Test with the Lilliefors correction. All the figures are significant at $\mathrm{p}<.001$

significant, allowing for the description of each of the profiles (see results in Table 2). These were named: High degree of knowledge and academic use of the Smartphone (High); Average degree of knowledge and use of the Smartphone (Average) and Low degree of knowledge and use of the Smartphone (Low).

On the other hand, the non-parametric analysis of the cluster variable and the dependent variables related to the time spent with the Smartphone, the perceived academic benefits and the interest in receiving training on the academic use of the Smartphone, showed some significant results (see Table 2). Therefore, it was concluded that there were differences in the time spent results between the three profiles, with the longest time spent found for the High profile, progressively decreasing from Average to Low. As for the benefits perceived and the interest in being trained to use the Smartphone for academic use, there were differences when comparing the Low profiles with the other two, as the Low profile students were the ones who detected the least number of positive aspects in the use of the Smartphone for 
Table 2 Contribution from each cluster analysis variable and dependent variables in the creation of student profiles

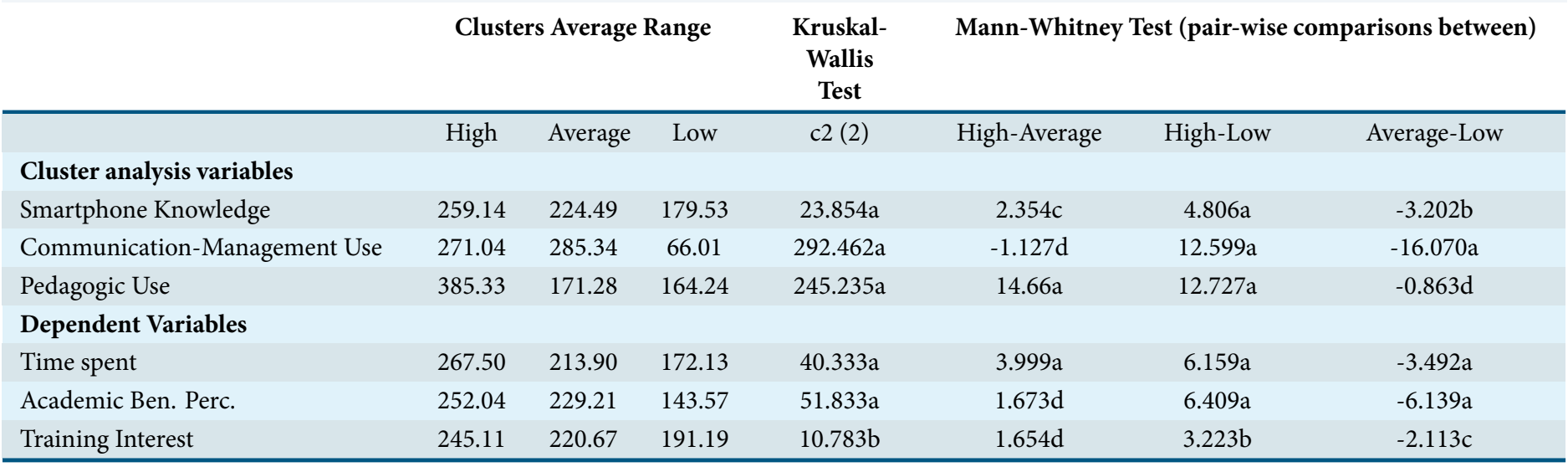

Note: $\mathrm{a}=\mathrm{p}<.001 ; \mathrm{b}=\mathrm{p}<.01 ; \mathrm{c}=\mathrm{p}<.05 ; \mathrm{d}=\mathrm{ns}$. The Mann-Whitney test has a statistical value of $\mathrm{Z} . \mathrm{N}=439$

academic tasks, and who had the least interest in training themselves for this aim.

The non-parametric analysis conducted with the cluster variable and the sociodemographic and academic variables (with Kruskal-Wallis tests) did not contribute greatly to the profiling of each cluster, as only the results related to gender were significant (see Table 3). Afterwards, between groups, non-parametric tests were conducted in order to identify a quintessential element within each profile: more specifically, a binomial test for a sample (value of 0.5) was used for gender, and the Chi-square test for a sample for the rest of the socio-demographic and academic variables (see results in table 3). These tests revealed that there were significant differences in each cluster (except in the Low cluster for the variable academic year). As we can see in the following figures, certain categories had a more relative weight on the sample distribution.

Table 3 Results of the intragroup and between group non-parametric tests

Non-parametric intra-group test

Between groups non-parametric test

\begin{tabular}{|c|c|c|c|c|}
\hline & High & Average & Low & \\
\hline \multirow[t]{2}{*}{ Gender } & $z=5.197$ & $z=-6.196$ & $z=2.425$ & $c 2(2)=6.42$ \\
\hline & $p<.001$ & $p<.001$ & $p<.05$ & $p<.05$ \\
\hline \multirow[t]{2}{*}{ Age } & c2 $(2)=32.56$ & c2 $(2)=73.43$ & $c 2(2)=54.45$ & c2 $(2)=0.77$ \\
\hline & $p<.001$ & $p<.001$ & $p<.001$ & $p=.682$ \\
\hline \multirow[t]{2}{*}{ Academic Year } & $c 2(4)=26.58$ & c2 $(4)=29.12$ & $c 2(4)=2.69$ & $c 2(2)=1.14$ \\
\hline & $p<.001$ & $p<.001$ & $p=.610$ & $p=.565$ \\
\hline \multirow[t]{2}{*}{ Area of knowledge } & $c 2(5)=139.51$ & $c 2(5)=358.62$ & $\mathrm{c} 2(5)=186.70$ & $\mathrm{c} 2(2)=0.568$ \\
\hline & $p<.001$ & $p<.001$ & $p<.001$ & $p=.753$ \\
\hline
\end{tabular}

To better understand the results found in the between groups non-parametric test, in the case of gender, a Mann-Whitney test was done, and it was confirmed that the differences were significant when comparing the Low profile to the High profile $(z=-2.36, p<.05)$ and with the Average profile $(z=-1.94, p=.05)$, as the Low profile grouped a greater percentage of men as compared to the High profile, and a lower percentage of women as compared to 
the Average profile (see figures 2, 3 and 4).

The characterization of the three clusters was conducted starting with the results presented and the analysis within each profile with the Wilcoxon matched pair test, using the variables that comprised the clusters (see statistics results in table 3, and their meaning in the following text).

The profile "High degree of knowledge and academic use of the Smartphone (High) contained the lowest percentage of students $(23.7 \%, N=104)$, and were defined by having the highest scores in knowledge as well as academic use of the Smartphone. In this profile, the pedagogic use prevailed over communication-management $(z=18.159, p<.001)$ and even knowledge $(z=18.076, p<.001)$.

These students were also characterized for using their Smartphones for longer periods of time, and without any differences with the Average profile; we detected an interest in training themselves and a greater perception of the academic benefits derived from the use of the Smartphone, as compared to the Low profile.

As for the sociodemographic and academic characteristics (see Figure 2), it should be noted that there was a greater presence of women $(76 \%$, significantly greater than in the Low profile), of students younger than 20 (22.1\%), aged between 20 and 25 years old (59.6\%), and $4^{\text {th }}$ year students (35.6\%). Likewise, a tendency for the students to be enrolled in the fields of knowledge of Social and Judicial Sciences (58.9\%) and Engineering and Architecture (23.2\%), was observed.

The profile "Average degree of knowledge and use of the Smartphone" (Average) was comprised by the largest percentage of students $(48.1 \%, \mathrm{~N}=211)$ from the sample. This profile was characterized by having an average level of knowledge, as well as by using the Smartphone mainly for communication-management tasks, and minimally for pedagogic tasks. The scores of these variables, shown according to significance, resulted in: the maximum score for the smartphone's use for communication-management followed by knowledge $(z=-7.78, p<.001)$ and lastly for its pedagogic use $(z=-12.65, p<.001)$, this last also being significantly distant from knowledge $(z=-12.61, p<.001)$.

Also, these students had average scores, placed between those from the High profile and Low profile, for three dependent variables: the time spent, the perceived academic benefits and the interest for receiving training that could grant them with knowledge, resources and strategies for the academic use of the Smartphone.

As for the socio-demographic and academic characteristics (see Figure 3), it should be mentioned that this profile maintained the predominance of the presence of women (71.6\%), although to a lesser degree than the profile discussed above (76\%). Likewise, it was composed mainly of students aged between 20 and 25 years old (61.1\%), in their $1^{\text {st }}$ year $(21.8 \%)$ and $4^{\text {th }}$ year $(33.2 \%)$ at university. Also, the students enrolled in the Social and Judicial Sciences (64.9\%) and Engineering and Architecture (16.6\%) predominated, although the first group were found in a greater proportion (58.9\%) and the second group in a lesser proportion (23.2\%) as compared to the previous profile analyzed.

The profile "Low level of knowledge and use of the Smartphone" (Low) included 28.2\% $(\mathrm{N}=124)$ of the students that participated in the study. Those who were included in this 


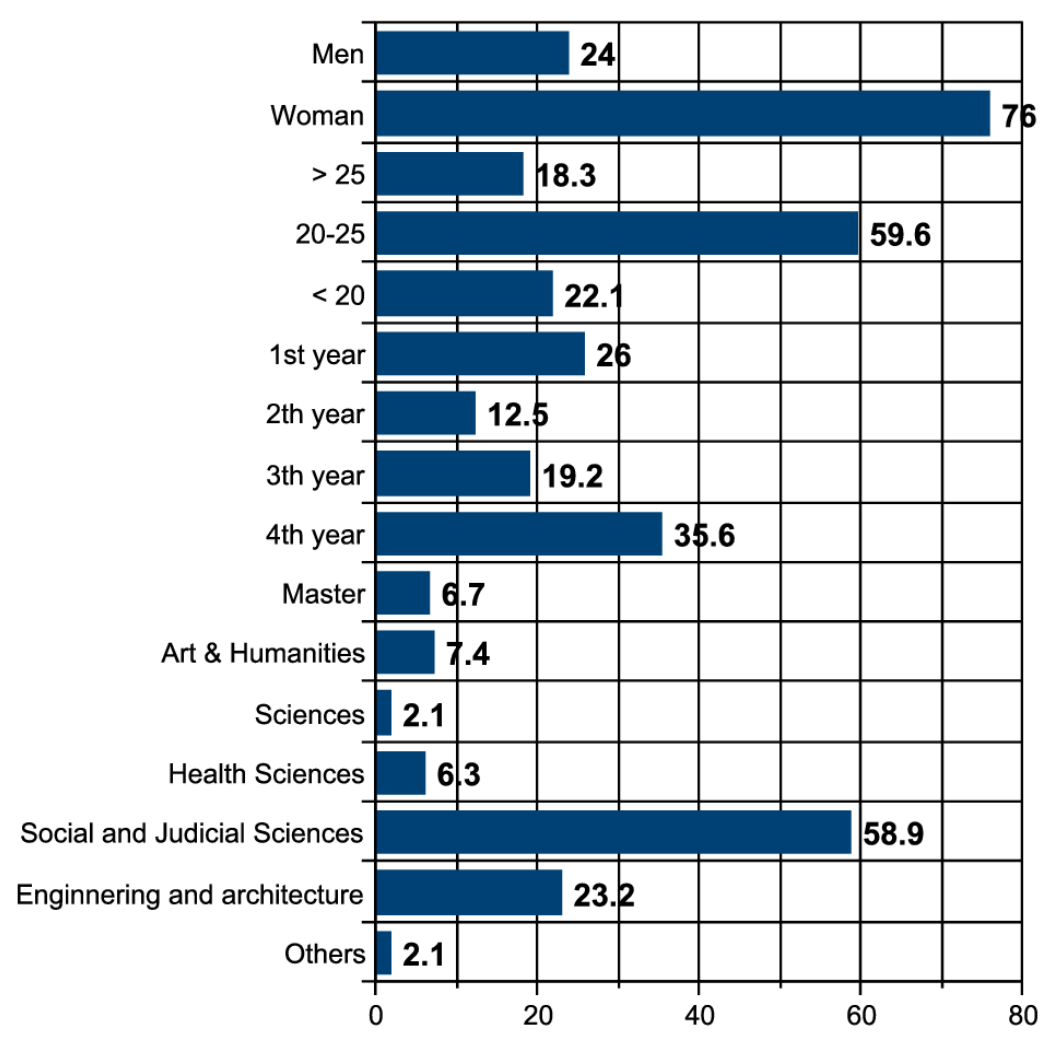

Figure 2 Representation of the High profile according to socio-demographic and academic variables.

group were characterized by their lower degree of knowledge and use of the Smartphone for communication-management tasks as compared to the other two profiles, as well as their use of the Smartphone for pedagogic tasks, which was just as scarce as the Average profile students. As for the between-groups differences among the variables from the cluster, knowledge was found to be higher, significantly followed by the use of the Smartphone for pedagogic tasks $(z=-8.808, p<.001)$ and for communication and management tasks $(z=$ $-9.672, p<.001)$, and between these last two, there were significant differences as well $(z=$ -9.528, $p<.001)$.

The scores received by the students with this low profile for the dependent variables in the study, were the lowest as compared to the other two profiles (see Table 3), in the time spent using the Smartphone as well as the perception they had of the benefits the device could grant for pedagogic tasks, and in their interest for training themselves in the use of the tool for academic activities.

In this profile, the students were characterized by a lower number of women as compared to the other two groups (61.3\% as opposed to $74 \%$ and $71.6 \%$ ), and also by grouping those students that were older (64.5\% were aged between 20 and 25 years old, and $19.4 \%$ were older than 25 years old). Also, we again observed that most were enrolled in the Social and Judicial Sciences (62.5\%) and Engineering and Architecture (15\%) degrees just as the previ- 


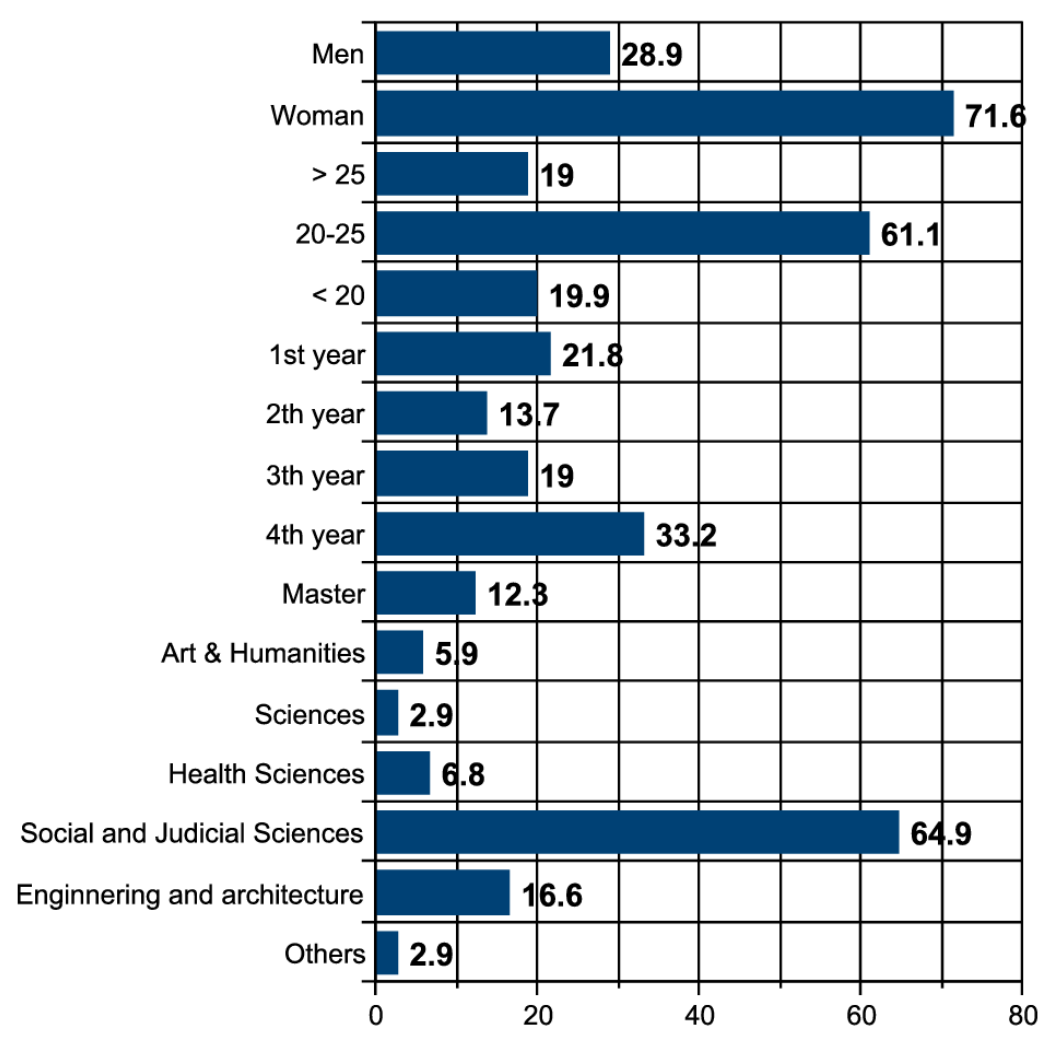

Figure 3 Representation of the Average profile according to socio-demographic and academic variables.

ous profiles, although it was interesting to note the increased percentage of students enrolled in the Sciences (5.8\%) as compared to the other two profiles (2.1\% and $2.9 \%$, respectively). Nonetheless, these last differences, as shown in Table 3, were not significant.

\section{DISCUSSION}

The general aim of this research study was to establish a classification of profiles of students in Higher Education, according to their knowledge and use of Smartphones, and to analyze their relation with the variables: interest towards training, benefits perceived with respect to the use of the tool in academics and the time spent using the Smartphone as a training resource.

In this sense, three profiles were defined, named: "High degree of knowledge and academic use of the Smartphone" (High), "Average degree of knowledge and use of the Smartphone" (Average) and "Low degree of knowledge and use of the Smartphone" (Low). The creation of three profiles coincided with the study by García et al. (2015). In the case of the above research, the profiles were constructed considering access to and attitudes towards technologies, as well as knowledge and use, which have been the key constitutive elements of the proposal presented in this article. On the other hand, in this research, the profiles they created for technological competence as well as for pedagogical competence, called 


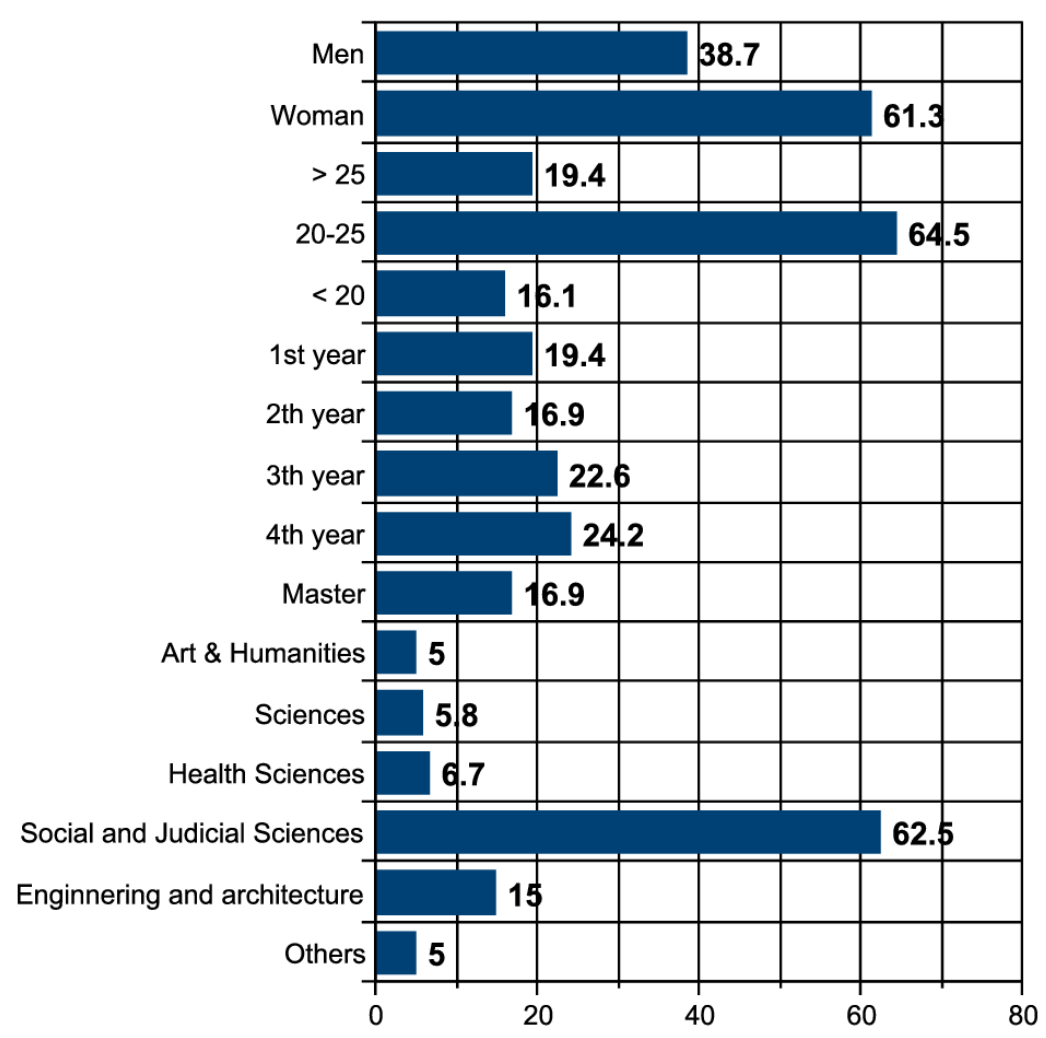

Figure 4 Representation of the Low profile according to socio-demographic and academic variables.

high, medium and low level, refer to the use of ICT in general, while this study is concretized in the Smartphone since, as Chen et al. (2017) point out, it is the device with the greatest potential for the development of learning.

The results of the present study show that the "Average" profile was the predominant one, within the context of the present study. It was characterized by a moderate knowledge and academic use of the Smartphone, followed by the "Low" profile, comprised of students who had scarce knowledge and use, academic as well as management and organization, of the Smartphone. Lastly, the profile that contained the least number of members was the "High" profile, with students that had a high degree of knowledge and use, academic as well as for management and communication, of the Smartphone.

It should be pointed out that the only significant difference found, related to the sociodemographic characteristic of the sample, was related to the student's gender. More specifically, women had significantly higher scores when compared to the men, in line with previous research studies (Carbonell et al., 2018; Kibona \& Mgaya, 2015; Sabater \& Bingen, 2015), which highlighted how women more frequently and intensively used the technologies.

Therefore, it was again evidenced, as shown by various authors (Kennedy et al., 2010; Lluna \& Pedreira, 2017; Yang et al., 2016), that the age of the subjects should not be used to place them in the generation of "Digital Natives", such as those, as defined to Prensky (2011), 
who possess all the abilities and competencies that allow them to safely and adequately use technologies. In this sense, when taking into account the evolution of the student's profiles as related to the use of technologies throughout the years, it can be seen that in general, and just as the results presented in this study show, the high profiles, related to a greater use, knowledge and/or use of tools, are composed by a lesser number of subjects (García et al., 2015). This result does not agree, however, with the results from a study by Henríquez et al. (2014), which showed that $58 \%$ of the students were placed in the advanced user profile as compared to the $42 \%$ who were placed in the low profile.

When analyzing the student's interest towards training, the benefits perceived and time spent using the Smartphone from the different profiles, the results showed that the students from the High profile, although a minority, showed a higher interest for training themselves, a wider perception of the benefits of the Smartphone as a pedagogic tool, and a greater use of the tool as compared to the students from the other two profiles. A non-negligible group of students (average and low profiles) still resisted adding technological tools that they use in their everyday lives, such as the Smartphone, for learning. The study by Razzaq et al. (2018), already pointed to the fact that the learning conducted by university students about the Smartphones was through their own experience or through help from their peers in specific situations. Although this is the general tendency, in line with the study's aims, the creation of three profiles allowed for the re-thinking of current training possibilities and methodologies, adjusting them to each of the clusters obtained. In agreement with Batanero and González (2015) and Tejedor et al. (2009), this would entail designing high-quality programs and activities. Teaching methods such as those proposed by Miguel (2006), could be adapted to new educational contexts through the pedagogical use of the Smartphone using modalities such as design thinking, flipped classroom, game-based learning or maker spaces, which are fundamental for promoting cooperation, creativity and critical construction of knowledge through technology (Lleixà et al., 2018; REDINE, 2019), are ideal for answering the heterogeneity found in the use and knowledge of the Smartphone by the students, since, as Tabuenca et al. (2013) point out, it is essential for the student to decide when and where to train autonomously.

This should be done, of course, by establishing nuances for each of the profiles, in relation to the degree of difficulty and autonomy demanded. An appropriate possibility for the medium and low profiles, would consist of the conducting of cooperative workshops, where the high-profile students could guide, orient, and help the rest of the classmates on the pedagogic use of the tool.

\section{LIMITATIONS AND FUTURE LINES OF RESEARCH}

In short, this article has presented three student profiles related to the knowledge and use of the Smartphone in Higher Education and their relationships with very interesting variables linked to training, time and benefits perceived.

It is deemed important to continue research on this subject matter, broadening the study to other contexts of international Higher Education, and likewise, to other educational 
spheres such as Secondary Schooling or Professional Training, as this research study was limited to the context of the University of Cantabria (Spain), and the results cannot be generalized.

Nevertheless, in light of the results presented previously, it is necessary to reflect upon the scarce percentage of students found in the "High degree of knowledge and academic use of the Smartphone" profile, and the limitations of the use of the Smartphone as a pedagogic tool in line with research studies conducted by Carbonell et al. (2018), Kibona and Mgaya (2015) and Rozgonjuk et al. (2018), in order to overcome the belief that the new generations per se belong to the generation of "Digital Natives", just as previously discussed. This reality encourages the development of different training trajectories that are adjusted to the needs of each group that will allow them to take advantage of the multiple possibilities offered by the new technologies, at the academic as well as the personal levels.

It would be interesting to continue researching, in line with the studies conducted by Razzaq et al. (2018) and Tabuenca et al. (2013), if the acquisition of technological and digital competencies through the day-to-day and academic use of mobile devices such as the Smartphone grants the students greater security in their autonomy and their making of decisions, based on the search for and contrasting of information, and reflection and action based on constructive criticism, individual as well as collaborative. Likewise, it would be interesting to verify if the use of the Smartphone favors a greater degree of interaction, communication and collaboration among equals, in an enriching, profound and stable manner, or in a pre-fabricated way (Gardner \& Davis, 2014), in order to preserve their e-identity and develop a sense of belonging to the largest group of equals.

In conclusion, an important research line would be one that contributes to delving into the reasons and motivations of why there is a large percentage of students who were placed in the average and low profiles of use of technology, a condition that seemed to evidence resistance to changing from the analog to the digital in the academic sphere. Furthermore, to what degree the professor's resistance against the educational use of the Smartphone affects this reality should also be investigated.

\section{REFERENCES}

Aguaded, J. I. (2014). Desde la Infoxicación al derecho a la Información. Comunicar, 42, 7-8. https://doi.org/10.3916/C42-2014-a1

Batanero, J. M. F., \& González, J. A. T. (2015). Actitudes docentes y buenas prácticas con TIC del profesorado de Educación Permanente de Adultos en Andalucía. Revista Complutense de Educación, 26, 33-49. https://doi.org/10.5209/rev_RCED.2015.v26.43812

Brazuelo, F., \& Cacheiro, M. L. (2010). Diseños de páginas web educativas para teléfonos móviles. EDUTEC, 32. Retrieved from http://edutec.rediris.es/Revelec2/revelec32/articulos_n32_pdf/ Edutec-e_n32_Brazuelo_Cacheiro.pdf

Brazuelo, F., \& Gallego, D. J. (2011). Mobile Learning. Los dispositivos móviles como recurso educativo (and others, Ed.). Sevilla: MAD.

Camacho, M. (2011). Mobile Learning: aproximación conceptual y prácticas colaborativas emergentes. Revista de ciències de l'educació, 2, 43-50. Revista de ciències de l’educació. https:// doi.org/10.17345/ute.2011.2.613 
Carbonell, X., Chamarro, A., Oberst, U., Rodrigo, B., \& Padres, M. (2018). Problematic Use of the Internet and Smartphones in University Students. International Journal of Environmental Research and Public Health, 15, 475-475. https://doi.org/10.3390/ijerph15030475

Cerezo, J. M. (2010). Smartphone. Toda la información al alcance de tu mano. Revista TELOS. Retrieved from http://telos.fundaciontelefonica.com/url-direct/pdf-genera-tor ?tipoContenido $=$ articuloTelos\&idContenido $=2010051309150001$ \&idioma $=$ es

Chen, O., Woolcott, G., \& Swellert, J. (2017). Using cognitive load theory to structure computerbased learning including MOOCs. Journal of Computer Assisted Learning, 33, 293-305. https://doi.org/10.1111/jcal.12188

Cisco. (2010). Retrieved from https://www.cisco.com/web/about/citizenship/socio-economic/ docs/TLS_Spanish.pdf

Cochrane, T., \& Bateman, R. (2010). Smartphones give you wings: Pedagogical affordances of mobile Web 2.0. Australasian Journal of Educational Technology, 26(1), 1-14. https://doi.org/ 10.14742/ajet.1098

Contreras, J., Herrera, A., \& Ramírez, M. S. (2009). Elementos instruccionales para el diseño y la producción de materiales educativos móviles. Revista Apertura de Innovación Educativa, 5(11). Retrieved from Recuperadodehttp://www.udgvirtual.udg.mx/apertura/num11/pdfs/ Apertura\%2011/TIC/TIC1.htm

Eisinga, R., Grotenhuis, M., \& Pelzer, B. (2013). The reliability of a two-item scale: Pearson, Cronbach, or Spearman-Brown? International journal of public health, 58(4), 637-642. https://doi.org/10.1007/s00038-012-0416-3

Ericsson. (2016). Retrieved from https://www.ericsson.com/res/docs/2016/ericsson-mobility -report-2016.pdf

Espinosa, J. K., Jiménez, J., Olabe, M., \& Basogain, X. (2006). Innovación docente para el desarrollo de competencias en el EEES. TAEE-2006. VII Congreso de Tecnologías Aplicadas a la Enseñanza de la Electrónica. Retrieved from http://campus.usal.es/ ofeees/ARTICULOS/ p216.pdf

Fundación Telefónica. (2016). La Sociedad de la Información en España. Madrid: Fundación Telefónica.

García, M. I. D., Ortí, C. B., Rodríguez, J. S., \& Abad, F. A. (2015). Perfiles de competencia tecnológica y pedagógica en estudiantes universitarios de titulaciones del ámbito educativo. In AIDIPE (Ed.), Investigar con y para la sociedad (Vol. 3, pp. 1513-1522). Bubok.

Gardner, H., \& Davis, K. (2014). La generación App. Cómo los jóvenes gestionan su identidad, su privacidad y su imaginación en el mundo digital. Barcelona: Paidós.

Hair, J., Black, B., Babin, B., \& Anderson, R. (2009). Multivariate Data Analysis. Upper Saddle River, NJ: Prentice-Hall.

Hartigan, J. A., \& Wong, M. A. (1979). Algorithm AS 136: a k-means clustering algorithm. Applied Statistics, 28(1), 100-100. https://doi.org/10.2307/2346830

Heflin, H., Shewmaker, J., \& Nguyen, J. (2017). Impact of mobile technology on student attitudes, engagement, and learning. Computers \& Education, 107, 91-99. https://doi.org/10.1016/ j.compedu.2017.01.006

Henríquez, P., González, C., \& Organista, J. (2014). Clasificación de perfiles de uso de Smartphones en estudiantes y docentes de la Universidad Autónoma de Baja California, México. Revista Complutense de Educación, 25(2), 245-270. https://doi.org/10.5209/rev_RCED.2014.v25.n2 .41437

Keegan, D. (2005). The incorporation of mobile learning into mainstream education and training. Retrieved from http://www.mlearn.org/mlearn2005/CD/papers/keegan1.pdf

Kennedy, G., Judd, T., Dalgarno, B., \& Waycott, J. (2010). Beyond natives and immigrants: exploring 
types of net generation students. Journal of Computer Assisted Learning, 26, 332-343. https:// doi.org/10.1111/j.1365-2729.2010.00371.x

Kibona, L., \& Mgaya, G. (2015). Smartphones' Effects on Academic Performance of Higher Learning Students. A Case of Ruaha Catholic University - Iringa. Tanzania. Journal of Multidisciplinary Engineering Science and Technology, 2(4), 777-784.

Lleixà, T., Gros, B., Mauri, T., \& Medina, J. L. (2018). Educación 2018-2020. Retos, tendencias y compromisos. Barcelona: IRE-UB.

Lluna, S., \& Pedreira, W. J. (2017). Los nativos digitales no existen. Bilbao: DEUSTO S.A.

malley, C. O., Vavoula, G., Glew, J. P., Taylor, J., \& Sharples, M. (2005). Guidelines for learning/teaching/tutoring in a mobile environment. Retrieved from http://hal.archives-ouvertes.fr/docs/00/ 69/62/44/PDF/OMalley-2005.pdf

Marcelo, C., Yot, C., \& Mayor, C. (2015). Enseñar con tecnologías digitales en la Universidad. Comunicar, 45, 117-124. https://doi.org/10.3916/C45-2015-12

Mcmillan, J., \& Schumacher, S. (2005). Investigación educativa. Madrid: Pearson. Investigación educativa.

Miguel, M. D. (2006). Metodologías de enseñanza y aprendizaje para el desarrollo de las competencias. Orientaciones para el profesorado universitario ante el Espacio Europeo de Educación Superior. Madrid: Alianza.

Mojarro, A., Duarte, A. M., Guzman, M. D., \& Aguaded, I. (2019). Mobile Learning in University Contexts Based on the Unified Theory of Acceptance and Use of Technology (UTAUT). Journal of New Approaches in Educational Research, 8(1), 7-17. https://doi.org/10.7821/ naer.2019.1.317

Picón, E., Varela, J., \& Real, E. (2003). Clasificación y Segmentación Post Hoc mediante el Análisis de Conglomerados. In J. P. Lévy \& J. Varela (Eds.), Análisis Multivariante para las Ciencias Sociales. Pearson Educación.

Prensky, M. (2001). Digital Natives, Digital Immigrants. On the Horizon, 9(5), 1-6. https://doi.org/ $10.1108 / 10748120110424816$

Prensky, M. (2011). Enseñar a nativos digitales. Madrid: Ediciones SM.

Quinn, C. (2000). mLearning: Mobile, Wireless, in your Pocket Learning. Retrieved from http:// www.linezine.com/2.1/features/cqmmwiyp.htm Recuperado de.

Ramos, A. I., Herrera, J. A., \& Ramírez, M. S. (2010). Desarrollo de habilidades cognitivas con aprendizaje móvil: un estudio de casos. Comunicar, 34, 201-209. https://doi.org/10.3916/ C34-2010-03-20

Razzaq, A., Samiha, Y. T., \& Anshari, M. (2018). Smartphone Habits and Behaviors in Supporting Students Self-Efficacy. International Journal of Emerging Technologies in Learning, 13(2), 94109. https://doi.org/10.3991/ijet.v13i02.7685

REDINE. (2019). Estrategias y metodologías didácticas: perspectivas actuales. Eindhoven, NL: Adaya Press.

Rozgonjuk, D., Saal, K., \& Täht, K. (2018). Problematic Smartphone Use, Deep and Surface Approaches to Learning, and Social Media Use in Lectures. International Journal of Environmental Research and Public Health, 15, 92-92. https://doi.org/10.3390/ijerph15010092

Sabater, C., \& Bingen, J. (2015). No, sin mi móvil. Diferencias de género y uso de las nuevas tecnologías. Icono 14, 13(1), 208-246. https://doi.org/10.7195/ri14.v13i1.722

Salcines-Talledo, I., \& González-Fernández, N. (2015). Los Smartphones en Educación Superior. Diseño y validación de dos instrumentos de recogida de información sobre la visión del alumnado. REOP. Revista Española de Orientación y Psicopedagogía, 26(3), 96-120. https://doi.org/10.5944/reop.vol.26.num.3.2015.16403

Sevillano, M. L. (2013). Enseñanza y aprendizaje con dispositivos móviles. In J. I. Aguaded 
\& J. Cabero (Eds.), Tecnologías y Medios para la Educación en la e-Sociedad (pp. 159-184). Madrid: Alianza Editorial.

Sung, Y. T., Change, K. E., \& Liu, T. C. (2016). The effects of integrating mobile devices with teaching and learning on students' learning performance: A meta-analysis and research synthesis. Computer \& Education, 94, 252-275. https://doi.org/10.1016/j.compedu.2015.11.008

Tabuenca, B., Verpoorten, D., Ternier, S., Westera, W., \& Specht, M. (2013). Fomento de la práctica reflexiva sobre el aprendizaje mediante el uso de tecnologías móviles. Revista de Educación a Distancia, 37, 1-14.

Tejedor, F. J., García-Valcárcel, A., \& Prada, S. (2009). Medida de actitudes del profesorado universitario hacia la integración de las TIC. Comunicar, 33, 115-124. https://doi.org/10.3916/ c33-2009-03-002

Tiana, A. (2013). Los cambios recientes en la formación inicial del profesorado en España: una reforma incompleta. Revista Española de Educación Comparada, 22, 39-58.

Traxler, J. (2005). Defining Mobile Learning. Retrieved from http://www.academia.edu/2810810/ Defining_mobile_learning

UNESCO. (1999). Declaración mundial sobre la Educación Superior en el siglo XXI: visión y acción. Wu, J. Y. (2015). University students'Motivated Attention and use of regulation strategies on social media. Computers \& Education, 89, 75-90. https://doi.org/10.1016/j.compedu.2015.08.016

Yang, J., Huang, R., \& null Kinshuk. (2016). The Learning Preferences of Digital Learners in K-12 Schools in China. Eurasia Journal of Mathematics, Science \& Technology Education, 12(4), 1047-1064. https://doi.org/10.12973/eurasia.2016.1254a 